\title{
Faculty Awareness and Attitudes Toward Academic Library Reference Services: A Measure of Communication
}

\begin{abstract}
A survey of the faculties at six colleges was undertaken to measure the degree to which the libraries of those institutions were communicating with the faculty concerning the availability of various references services. The results demonstrated that the average faculty member was aware of barely half the services actually available. Variables of academic rank, length of teaching, and amount of library and reference use were some of the factors shown to affect faculty awareness of library service.
\end{abstract}

COMMUNICATION BETWEEN THE FACULTY and the academic librarian seriously affects the functioning of academic library service. Without adequate communication between these parties, the library's goals of educational service cannot be fully realized, the instructional and research needs of the faculty cannot be fully realized, the instructiondent cannot benefit fully from the resources for education and enlightenment that the academic library has to offer. Whatever the quality and quantity of services provided by the library for faculty and students, those services will lack effectiveness if their availability is not made known.

Communication between librarian and patron, although a critical problem, is not extensively covered by the literature of librarianship. Most literature, dealing with this topic, however, only implies the existence of obstacles to effective communication between the aca-

Jerold Nelson is an assistant professor at the School of Librarianship, University of Washington, Seattle. demic librarian and the faculty. For example, Knapp, in her study of one liberal arts college library, found a "widespread lack of understanding or, at least, consensus among faculty and staff about what a library can and should contribute to the college-indeed, about what a library is." 1 During her work at Monteith College, she indicated that librarians in the program were never freely accepted by the teaching faculty as members in the teaching process, a failure she partially blamed on problems of communication. ${ }^{2}$ De Hart's experiment in providing specialized information services to the faculty did not succeed because librarians and faculty members were unwilling to discard preconceptions; some would not even discuss the subject. ${ }^{3}$ Schumacher's analysis of a Small College Information System reported that "faculty ... appear to be generally unaware of current library holdings and services and of how best to make use of (those) facilities and services." 4 Leonard and his associates discovered that faculty members at Colorado colleges and universities fre- 
quently thought that libraries should make greater efforts to "publicize services available to faculty (members) ... and to explain what these services entail."5 Lawson's study of university reference services reported that the library's failure to publicize the availability of reference activities resulted in limited demands from the faculty for the activities. ${ }^{6}$

Although these cases suggest problems in communication, there exists a lack of evidence necessary to evaluate the extent of such problems, as well as a method to measure levels of faculty-librarian communication.

\section{METHODOLOGY}

Faculty members were questioned about the availability of reference services at their college library; their knowledge was assumed to be based on direct or indirect communication with librarians at the college. Six institutions were selected from the California system of state colleges and universities: all had similar academic objectives, similar levels of resources and formulas for resource allocation, and a similar range of reference services. One thousand sixty-seven faculty members, representing a 30 percent random sample from the full-time faculties of the college, were sent a questionnaire listing thirteen reference services, eleven of which were offered by each of the libraries on a regular basis (see Table 1). For each service, the respondents were asked to indicate either (1) that the service was available, (2) that it was not available, or (3) that they did not know the status of its availability. A negative or "don't know" response for the eleven available services or a positive or "don't know" response for the two services not offered was taken to show inadequate communication between the library and the faculty.

Seventy-three percent of the corrected sample returned the questionnaires. ${ }^{7}$
Available descriptive characteristics of the respondent and nonrespondent groups, including discipline, academic rank, and years of service at the institution, were compared and tested by the chi-square method. ${ }^{8}$ There were no significant differences and the response was accordingly accepted as a fair representation of the entire sample. Since the distribution of awareness data approximated a normal curve, the mean was selected as an appropriate measure of central tendency.

\section{Findings}

Tabulation of survey data (Table 2) provided the following information.

(1) The sample's overall mean awareness score (M.A.S.) of 6.2 significantly represented less than half of the thirteen services listed. ${ }^{9}$

(2) Faculty from the humanities and from education had a higher level of awareness than faculty from other teaching areas, but their superiority is statistically significant only in comparison to the science group, which rated lowest.

(3) According to the data, level of awareness is directly related to faculty rank, although the difference in M.A.S. between full and associate professors was not statistically significant.

(4) Faculty who indicated at least weekly use of the library's reference services had a higher M.A.S. than those who used the services less frequently. Even a moderate use of reference services (1-2 times per month) produce a greater than average awareness of their availability. The small group with a high level of reference use had a mean awareness that was much higher than any subgroup in the study (M.A.S. = 7.8 ).

(5) The M.A.S. of faculty who had served on at least one committee dealing with library affairs was higher than the M.A.S. of those who had not served.

(6) Faculty who had been teaching 
TABLE 1

Summary of Responses by Faculty to Questionnaire on Reference Services $(\mathrm{N}=694)$

\begin{tabular}{llrrrr}
\hline \hline $\begin{array}{c}\text { Classification } \\
\text { of Service }\end{array}$ & \multicolumn{1}{c}{ Reference Service Provided } & Yes & No & $\begin{array}{c}\text { Don't } \\
\text { Know }\end{array}$ & $\begin{array}{c}\text { No } \\
\text { Response }\end{array}$ \\
\hline \multirow{2}{*}{$\begin{array}{l}\text { Education- } \\
\text { General }\end{array}$} & Advice and Assistance in Use of the Library & $\%$ & $\%$ & $\%$ & $\%$ \\
\hline Education- & Library Bulletins and Handbooks & 74 & 1 & 4 & 1 \\
Special & Library Instruction for Classes & 10 & 14 & 2 \\
\hline & Lists of Reference Sources for Specific Classes & 17 & 14 & 31 & 1 \\
& Bibliographies for General Distribution & 38 & 26 & 34 & 2 \\
\hline Information- & Vertical Files & 40 & 7 & 52 & 1 \\
Materials & Interlibrary Borrowing & 85 & 2 & 13 & 1 \\
\hline Information- & Answer to a Factual Question & 61 & 6 & 32 & 1 \\
Questions & Answer to a Factual Question-Phone & 36 & 8 & 55 & 1 \\
& Answer Requiring a Search & 22 & 14 & 62 & 1 \\
& Answer Requiring Information from & 40 & 9 & 51 & 1 \\
\hline Outside the Library & Demand Bibliographies (not regularly available) & 7 & 22 & 70 & 1 \\
Information - & Literature Search (not regularly available) & 5 & 21 & 73 & 1 \\
\hline Special & & & & & \\
\hline
\end{tabular}

TABLE 2

Faculty Mean Awareness Scores (scale $=0-13$ )

\begin{tabular}{|c|c|c|c|c|c|c|c|}
\hline Category & Mean & $\begin{array}{l}\text { Standard } \\
\text { Deviation }\end{array}$ & No. & Category & Mean & $\begin{array}{l}\text { Standard } \\
\text { Deviation }\end{array}$ & No. \\
\hline OVERALL & 6.2 & 2.4 & 663 & \multicolumn{4}{|l|}{ BY LIBRARY USE } \\
\hline BY TEACHING AREA & & & & \multirow{2}{*}{$\begin{array}{l}\text { More Than Weekly } \\
\text { 3-4 Times per Month }\end{array}$} & \multirow{2}{*}{$\begin{array}{l}7.1 \\
6.4\end{array}$} & \multirow{2}{*}{$\begin{array}{l}2.4 \\
2.1\end{array}$} & \multirow{2}{*}{212} \\
\hline Humanities & 6.5 & 2.4 & 163 & & & & \\
\hline Education & 6.5 & 2.5 & 108 & 1-2 Times per Month & 5.6 & 2.3 & 185 \\
\hline Applied Arts & & & & Rarely or Never & 4.2 & 2.3 & 55 \\
\hline \& Sciences & 6.3 & 2.4 & 134 & \multicolumn{4}{|c|}{ BY COMMITTEE MEMBERSHIP } \\
\hline Social Sciences & 6.1 & 2.3 & 161 & Members & 6.9 & 2.4 & 237 \\
\hline Sciences & 5.6 & 2.7 & 97 & Nonmembers & 5.9 & 2.4 & 423 \\
\hline BY FACULTY RANK & & & & \multicolumn{4}{|c|}{ BY LENGTH OF SERVICE } \\
\hline Professor & 6.9 & 2.2 & 209 & 10 Years or More & 7.2 & 2.1 & 198 \\
\hline Associate Professor & 6.6 & 2.6 & 191 & 4-9 Years & 6.2 & 2.4 & 293 \\
\hline Assistant Professor & & & & 1-3 Years & 5.2 & 2.4 & 168 \\
\hline \& Instructor & 5.4 & 2.2 & 263 & \\
\hline BY REFERENCE USE & & & & \multicolumn{4}{|l|}{ College $A$} \\
\hline More Than Weekly & 7.8 & 2.3 & 61 & College $B$ & 6.3 & 2.4 & 172 \\
\hline 3-4 Times per Month & 7.1 & 2.3 & 104 & College $C$ & 6.2 & 2.4 & 139 \\
\hline 1-2 Times per Month & 6.7 & 2.3 & 207 & College $D$ & 6.0 & 2.4 & 104 \\
\hline Rarely or Never & 5.3 & 2.2 & 283 & College $E$ & 5.9 & 2.4 & 76 \\
\hline & & & & College $F$ & 5.8 & 2.6 & 58 \\
\hline
\end{tabular}

at the college for at least ten years had a higher M.A.S. than those who had taught for a lesser period; level of awareness varied directly with length of service at the college.

(7) The data indicated that the six colleges, all similar in function and all under a highly centralized state system, demonstrated a range of awareness lev- els. Some libraries in the sample seem to be more effective in communicating the availability of services to their faculty clients. One college, designated here as College $A$, had a M.A.S. substantially higher than any of the other colleges. Differences in M.A.S. among the other colleges were not statistically significant.

In general, the most widely recognized 
educational service of the library was the providing of advice and assistance in the use of the library. Ninety-five percent of the respondents were aware that this service was available (see Figure 1 ). The most widely recognized informational service was the interlibrary borrowing activity, with an awareness response of 85 percent. The least widely recognized of the available services was the educational service of providing reference source lists tailored to specific class requirements (17 percent) and the informational service of answering questions that require a search for the answer (22 percent). Other services ranged widely between the extremes.

One variable which accounted for some of the observed variation seems to be level of faculty need. Many faculty feel a more intimate need for the service of interlibrary borrowing than for lists of reference sources tailored to specific classes for student use, and they inform themselves accordingly. Universality of demand for a service and the ease with which it can be provided also seem to affect awareness. Advice and assistance in the use of the library rates high on both counts.

Moreover, a combination of poor communication with a low level of refence activity seems to lower awareness of some services. Self-evident services (see Table 3)-advice and assistance in library use, interlibrary borrowing, and the distribution of library handbooks and bulletins-maintain a higher M.A.S. than do services which require some deliberate act of communication, either as a request for information by the faculty or as an announcement of availability by the library. Although level of need, universality of demand, and ease of provision, complicate the effect of this distinction by communication, the evidence furnishes at least minimal support for the inference that as an act of communication becomes more of a requirement, knowledge of the avail- ability of a service tends to diminish. That inference, in turn, supports the basic premise of the investigation, that communication is less than adequate between the faculty and librarians in academic institutions.

The findings also revealed the relative degree to which the various colleges succeeded in communicating the availability of the services they claimed to offer: each library had special success in communicating certain services. Table 4 indicates that College $A$, with the highest M.A.S., ranked from first to fourth among the colleges with respect to awareness of individual services. College $F$, with the lowest M.A.S., in one case achieved a tie for a highest awareness ranking, and it ranked second in awareness for another service. College $B$, with the second highest M.A.S., ranked sixth in four of the eleven categories. This information seems to suggest that the libraries tended to emphasize various categories of service. Faculty members at College $A$ were particularly aware of all the services that fell into the category of providing information. Its library and reference staff seem to have been active in promoting what Rothstein has called a maximum level of reference service. ${ }^{10}$

The survey also furnished information about faculty attitudes toward the utility of the services listed. Respondents were asked to indicate the degree to which they considered each service to be desirable, whether they thought the service was currently available or not. A majority of respondents expressed a favorable attitude toward each of the available services (see Table 5). Faculty members were least likely to react favorably to the specialized information services not currently being offered by the libraries on a regular basis, and toward the provision of lists of reference sources for their classes. Marginal comments appended to some questionnaires further explained the nature of facul- 


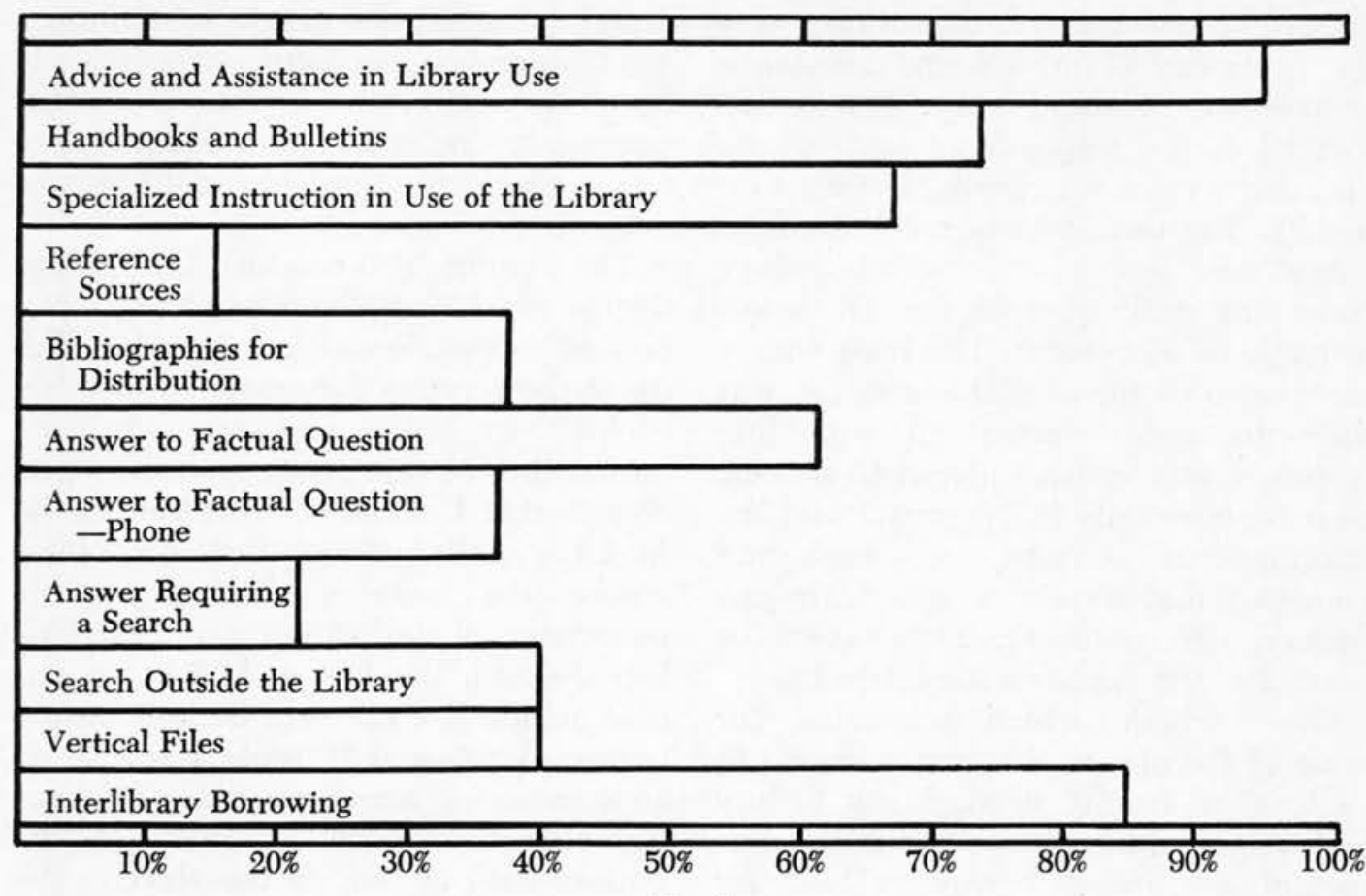

Fig. 1

Overall Faculty Awareness of Eleven Available Services $(N=694)$

TABLE 3

Classification of Reference Services by Mode of Communication

\begin{tabular}{llc}
\hline \hline \multicolumn{1}{c}{ Classification of Service } & \multicolumn{1}{c}{ Category of Service } & $\begin{array}{c}\text { Level of } \\
\text { Awareness }\end{array}$ \\
\hline $\begin{array}{l}\text { SELF-EVIDENT SERVICES } \\
\text { Basic Services }\end{array}$ & $\begin{array}{l}\text { Advice and Assistance in the Use of the Library } \\
\text { Interlibrary Borrowing Service }\end{array}$ & 95 \\
$\quad \begin{array}{l}\text { Services Made Self-Evident by } \\
\text { Distribution at Library Service }\end{array}$ & Library Bulletins and Handbooks & 85 \\
$\quad$ Points & Bibliographies for General Distribution & 74 \\
SERVICES WHICH MAY OR & Maintenance of Pamphlet and Other Vertical & \\
MAY NOT BE SELF-EVIDENT & Files & 40 \\
SERVICES WHICH REQUIRE AN & Library Instruction for Classes & 65 \\
ACT OF COMMUNICATION TO & Answer to a Factual Question & 61 \\
ANNOUNCE THEIR AVAILABILITY & Answer Requiring Information from Outside & 40 \\
& the Library & 40 \\
& Answer to a Factual Question-Phone & 36 \\
& Answer Requiring a Search & 22 \\
& Lists of Reference Sources for Specific Classes & 17 \\
\hline
\end{tabular}

ty objections to certain services. The objections centered around two points. (1) Several respondents considered the question of the cost versus the potential benefit of specialized services. "I could agree on all the above 'shoulds' if the budget were no problem." "If I were to complete this questionnaire to reflect my desires rather than my realistic assessment of the current library and budget- 
TABLE 4

Awareness of Individual Services-By College

\begin{tabular}{|c|c|c|c|c|c|c|c|c|c|c|c|c|c|}
\hline \multirow[b]{2}{*}{ Service } & \multicolumn{6}{|c|}{ By Rank } & \multicolumn{7}{|c|}{ By Percentage } \\
\hline & A & $B$ & C & $D$ & E & $F$ & $A$ & $B$ & c & $D$ & $E$ & $F$ & $\begin{array}{c}\text { Over- } \\
\text { all }\end{array}$ \\
\hline & & & & & & & $\%$ & $\%$ & $\%$ & $\%$ & $\%$ & $\%$ & $\%$ \\
\hline Advice and Assistance & 3 & 2 & 1 & 5 & 3 & 6 & 95 & 96 & 97 & 93 & 95 & 90 & 95 \\
\hline Bulletins and Handbooks & 4 & $\overline{3}$ & $\hat{1}$ & 5 & 6 & 1 & 64 & 82 & 85 & 63 & 59 & 85 & 74 \\
\hline Library Instruction for Classes & 1 & 5 & 3 & 6 & 2 & 4 & 74 & 59 & 70 & 58 & 71 & 60 & 65 \\
\hline Lists of Reference Sources for Classes & 4 & 5 & 2 & 3 & $\overline{1}$ & 5 & 16 & 13 & 20 & 18 & 21 & 13 & 17 \\
\hline Bibliographies for Distribution & 3 & 1 & $\overline{6}$ & 5 & 4 & 2 & 31 & 60 & 25 & 27 & 28 & 53 & 38 \\
\hline Answer to a Factual Question & 1 & 6 & 3 & 2 & 4 & 4 & 76 & 53 & 58 & 68 & 55 & 55 & 61 \\
\hline Answer to a Factual Question-Phone & 1 & 6 & 5 & 4 & 2 & 3 & 48 & 28 & 34 & 36 & 39 & 37 & 36 \\
\hline Answer Requiring a Search & 1 & 6 & 3 & 5 & 2 & 4 & 37 & 16 & 21 & 19 & 24 & 20 & 22 \\
\hline Answer Requiring Information from & & & & & & & & & & & & & \\
\hline Outside the Library & 1 & 6 & 2 & 3 & 5 & 4 & 60 & 33 & 38 & 37 & 34 & 35 & 40 \\
\hline Vertical Files & 1 & 2 & 3 & 3 & 5 & 6 & 48 & 46 & 41 & 41 & 26 & 25 & 40 \\
\hline Interlibrary Borrowing & 1 & $\overline{2}$ & 5 & 3 & 3 & 6 & 96 & 87 & 80 & 83 & 83 & $\overline{75}$ & 85 \\
\hline
\end{tabular}

TABLE 5

Summary of Attitude Responses to Individual Services ( $N=668$ )

\begin{tabular}{|c|c|c|c|c|}
\hline Classification & Service & $\begin{array}{c}\text { Favorable } \\
\text { Attitude }\end{array}$ & $\begin{array}{l}\text { Unfavorable } \\
\text { Attitude }\end{array}$ & $\begin{array}{l}\text { No } \\
\text { Response }\end{array}$ \\
\hline Education-General & $\begin{array}{l}\text { Advice and Assistance } \\
\text { Bulletins and Handbooks }\end{array}$ & $\begin{array}{r}\% \\
89 \\
87\end{array}$ & $\stackrel{\%}{\%}$ & $\begin{array}{r}\% \\
10\end{array}$ \\
\hline Education-Special & $\begin{array}{l}\text { Library Instruction for Classes } \\
\text { Lists of Reference Sources for Classes } \\
\text { Bibliographies for Distribution }\end{array}$ & $\begin{array}{l}81 \\
54 \\
66\end{array}$ & $\begin{array}{l}10 \\
38 \\
26\end{array}$ & $\begin{array}{l}9 \\
8 \\
8\end{array}$ \\
\hline Information-Materials & $\begin{array}{l}\text { Vertical Files } \\
\text { Interlibrary Borrowing }\end{array}$ & $\begin{array}{l}70 \\
89\end{array}$ & $\begin{array}{r}20 \\
2\end{array}$ & $\begin{array}{r}10 \\
9\end{array}$ \\
\hline Information-Questions & $\begin{array}{l}\text { Answer to a Factual Question } \\
\text { Answer to a Factual Question-Phone } \\
\text { Answer Requiring a Search } \\
\text { Answer Requiring Information from } \\
\text { Outside the Library }\end{array}$ & $\begin{array}{l}81 \\
71 \\
60 \\
77\end{array}$ & $\begin{array}{l}11 \\
21 \\
31 \\
14\end{array}$ & $\begin{array}{l}8 \\
8 \\
9 \\
9\end{array}$ \\
\hline Information-Special & $\begin{array}{l}\text { Demand Bibliographies (not regularly } \\
\text { available) } \\
\text { Literature Search (not regularly available) }\end{array}$ & 45 & 48 & 7 \\
\hline
\end{tabular}

ary situation ..." "I would like to have these services, but when it comes to money to pay for them, I would rather put the money into other things. . .." (2) Others questioned the capability of the librarian to satisfy their serious information needs. "I feel only the user can discriminate and select." "The researcher should be (looking up specific questions) for he has the judgment to interpret the information." "I . . . would not trust any bibliographic . . . work conducted by library reference people as being complete...."

Despite these kinds of reservations, however, the number of people who approved of a service was larger than the number who had known the service was already available for every service except the basic activity of providing assistance in the use of the library. The minimal inference to be drawn from this is that for nearly every service, there were individuals who desired the 
service without knowing that it was already being offered.

\section{SUMMary AND CONCLUSION}

This study demonstrates that the average faculty member who responded to the questionnaire was aware of only 50 percent of the reference services available to him from his college library. Variables of academic rank, length of service at the college, service on committees dealing with library affairs, and amount of library and reference use were all related directly to degree of awareness. Surprisingly, social scientists showed a relatively low level of awareness. Intuitive estimates of potential friends for the library among members of the faculty have usually rated social scientists highly.11 Follow-up interviews with a small sample of respondents did suggest that social scientists tended to be more critical of librarians' performance than were faculty members from the humanities; it was not clear, however, whether their dissatisfaction resulted from a higher level of information need and expectation or whether librarians actually performed less competently in the area of the social sciences.

Although academic libraries which are closely related in mission and in resource allocation might tend to define and to execute their responsibilities in similar fashion, an exceptional institution, with the same resources and constraints, may demonstrate the capacity to discharge its defined responsibilities with greater effectiveness. In this case, the library of College $A$ indicated a special capacity for successful communication with the faculty, a capacity that cannot be explained simply in terms of greater resources. The analysis of awareness of individual services (Table 4) indicated that the library of College A was also more successful than others in promoting information services requiring maximum level of reference ser- vice. Furthermore, it was more successful in bringing to the attention of the faculty those services requiring communication to be announced. Follow-up interviews indicated that College A librarians were the most active of the group in book selection and collection development, and both librarians and faculty interviewees agreed that this was an important common concern. Both faculty members and librarians from College A spoke enthusiastically of a tradition of public service that had been promoted by the library administration from the time the college had been founded. Finally, librarians from College A seemed to display a higher degree of personal initiative than did other librarians in establishing and in maintaining contact with faculty members.

Although College $A$ did appear to be most effective in promoting awareness for the low visibility services, certain services were still not well known at any of the colleges, particularly those services surpassing the superficial and the commonplace. This low level of awareness has partially been a product of a low level of library activity in providing specific services energetically on a dayto-day basis. Also, low awareness has probably been the result of a low level of faculty confidence in the competence of librarians. With emphasis on the low awareness services, it seems that librarians have not realized the potential available to them for communication and for consistent and confident performance.

Given the range of responsibilities of many academic reference librarians, such realization is no easy task. The problem is complicated by those academic library administrators who have assigned low priority to questions of communication, and even to questions of public service, in their genuine (and justified) concern for the acquisition and organization of the masses of information that are currently threaten- 
ing to overwhelm us. The result seems to be that some academic libraries are slighting a share of their responsibility to the individual client who is the ultimate rationale for most of the library's activities.

In this study, the faculty has indicated that it desires a full range of services. If the library is to maintain and enlarge services, librarians must be prepared and encouraged to exercise initia- tive in using more library resources to promote available services as well as to provide them consistently, competently, and vigorously. A first step should be to establish channels to communicate the availability of services to the faculty. The principal burden of responsibility for that communication resides with the academic library and its corps of librarians.

\section{REFERENCES}

1. Patricia B. Knapp, College Teaching and the College Library (Chicago: American Library Association, 1959), p.93 (ACRL Monograph No. 23).

2. - The Monteith College Library Experiment (New York: Scarecrow Press, 1966 ), p.30-32.

3. Florence De Hart, "The Application of Special Library Services and Techniques to the College Library," CRL 27:152 (March 1966).

4. Anne W. Schumacher, A Small College Information System: An Analysis and Recommendations (St. Paul: Hamline University, 1968), p.III-2.

5. Lawrence E. Leonard, et al., Centralized Book Processing: A Feasibility Study Based on Colorado Academic Libraries (Metuchen, N.J.: Scarecrow Press, 1969), p.220.

6. A. Venable Lawson, Reference Service in University Libraries: Two Case Studies (Dissertation, Columbia University, 1969), p.293.

7. The original sample of 112 faculty members no longer qualified as part of the survey population, usually because they had left the college during the preceding year.

8. All tests of statistical significance were carried out at an alpha level of .05 .

9. This finding is less conclusive than it might have been because of complications introduced by the two services on the list not regularly offered by the libraries. It is likely that some respondents did receive those services on an individual basis and were therefore justified in providing an affirmative answer with respect to them. A retabulation excluding responses to the two services in question produced an overall M.A.S. or just over 50 percent (M.A.S. = 5.8 on a scale of $0-11$ ).

10. Rothstein, "Reference Service: The New Dimension in Librarianship," in Reference Services (Hamden, Conn.: Shoestring Press, 1964), p.40.

11. See, for example, Knapp's recent suggestion that social scientists might be singled out as being particularly sympathetic toward working with librarians to provide education in the use of the library for students. She suggests that many social sciences rely heavily on the library as a source for data and they also do not often have independent programs for developing library competence for their students. Knapp, "The Library, the Undergraduate and the Teaching Faculty," a paper presented at an Institute on Training for Service in Undergraduate Libraries, sponsored by the University Library, University of California, San Diego, August 17-21, 1970. Available from ERIC (Ed 042 475). 